\title{
Procurement challenges in the Zimbabwean public sector: A preliminary study
}

\author{
Authors: \\ Abel Dzuke ${ }^{1}$ \\ Micheline J.A. Naude

\begin{abstract}
Affiliations:
${ }^{1}$ Department of

Management, Information

Technology and Governance,

University of KwaZulu-Natal,

South Africa
\end{abstract}

\section{Correspondence to:} \\ Micheline Naude \\ Email: \\ naudem@ukzn.ac.za \\ Postal address: \\ Private Bag X01, \\ Pietermaritzburg 3209, \\ South Africa \\ Dates: \\ Received: 25 Nov. 2015 \\ Accepted: 16 Mar. 2015 \\ Published: 30 Apr. 2015 \\ How to cite this article: \\ Dzuke, A. \& Naude, M.J.A., \\ 2015, 'Procurement \\ challenges in the \\ Zimbabwean public sector: \\ A preliminary study', Journal \\ of Transport and Supply \\ Chain Management 9(1), Art. \\ \#166, 9 pages. http://dx.doi. \\ org/10.4102/jtscm.v9i1.166

\section{Copyright:} \\ C 2015. The Authors. \\ Licensee: AOSIS \\ OpenJournals. This work is \\ licensed under the Creative \\ Commons Attribution \\ License.
}

Read online:

Scan this QR code with your smart phone or mobile device to read online.
Background: State Procurement Board procedures and the public procurement process have been blamed for the lagging behind of government projects that impact on public service delivery in Zimbabwe.

Objectives: This article provides insight into challenges resulting from the legal framework for public procurement in Zimbabwe that detract from service delivery.

Method: Empirical data was collected through in-depth interviews with five participants at five public entities, using a semi-structured interview guide. Content analysis was used to analyse the primary data.

Results: The findings revealed various challenges in the public procurement process that detract from service delivery. These include a lack of strategic recognition of the procurement function and procurement policy; a lack of professional, managerial and leadership skills; a lack of appropriated funds from Treasury; and a lack of accountability in the procurement process.

Conclusion: There is a dearth of research on the public procurement process and its efficiency in Zimbabwe, and this study contributes to the existing body of knowledge by identifying areas through which public procurement can be improved in Zimbabwe.

\section{Introduction}

Globally, public procurement occupies a key role in service delivery and performance of government departments and public entities. Over and above the fiduciary obligation of a particular government administration to deliver goods and services to citizens, public procurement is essential for the execution of public contracts (Uyarra \& Flanagan 2009). Indeed, public procurement involves all the processes related to the acquisition of goods and services by government, parastatals and local public authorities (Roodhooft \& Abbeele 2006).

The public sector consists of government departments and public entities, such as a roads and transport services, communication systems and health services. These entities provide goods or services to the public (Institute of Internal Auditors 2011) and are provided through public procurement (Uyarra \& Flanagan 2009).

Public procurement is explained as the process by which public sector organisations - ministries, parastatals and local authorities - acquire goods and services. Such goods and services include: standard items such as stationery; standard to more complex expenditures such as the construction of roads; and key services to citizens such as education (Roodhooft \& Abbeele 2006). Because of the importance of public procurement, the public procurement process in most countries is governed by public procurement laws and regulatory frameworks.

Dobler, Burt and Starling (2003:593) remark that the main objective of public procurement is to: reduce costs; benefit from specialist expertise; promote transparency; protect public funds; and challenge corrupt tendencies. Monczka et al. (2008:109) state that the main objective of public procurement is to use public funds efficiently and provide service delivery through the use of competition. According to the United Nations Development Programme (UNDP/IAPSO 2006:1), public procurement plays a pivotal role in government performance and is measured through service delivery.

The differences in the legal framework in different countries affect the implementation and results of the public procurement process and service delivery. For example, in Zimbabwe, public procurement is centralised at the State Procurement Board (SPB). According to the Procurement Act (Chapter 22:14) Section 5(1)(2) (Zimbabwe Government 1999), the mandate of the SPB is to 
regulate and manage the public procurement process in all government ministries, public entities and local authorities in line with public procurement law.

SPB procedures and the public procurement process have been criticised for the lagging behind of government projects, such as the construction of roads, provision of clean water and sewer reticulation, amongst others (The Herald 20 January 2013). There is constant criticism of inefficiency in the awarding of tenders for various projects (Musanzikwa 2013), which results in the delay or non-completion of crucial projects. Not meeting targets has detracted from service delivery.

Against this background, the purpose of this article is to (1) provide an overview of the public procurement process in Zimbabwe and (2) identify procurement challenges in the Zimbabwe public sector that detract from service delivery. This research is original and contributes to the existing body of knowledge by identifying areas in which public procurement can be improved in Zimbabwe. With regard to the wider procurement spectrum, the study aims to highlight the need to move from 'purchasing' to 'procurement', as it is a powerful tool for economic development and public sector performance in emerging economies.

\section{Literature review}

\section{Public procurement}

Public procurement refers to the acquisition of goods, services and works by a procuring entity using public funds. Public funds are collected through taxes and must be spent in a transparent and accountable manner (Hui et al. 2011). Many countries have reformed procurement laws and regulations in order to improve transparency and accountability. However, the major challenge has been the failure by procurement officials to comply with these regulations (Lisa 2010).

Public procurement consumes a significant proportion of government expenditure. Mahmood (2010:12) suggests that public procurement constitutes $18.42 \%$ of the world's gross domestic product (GDP). It is estimated that public procurement represents between $9 \%$ and $13 \%$ of emerging economies' GDP. Indeed, public procurement is an important function that requires close attention as procurement officials in public entities are governed by regulations, policies and procedures (Odhiambo \& Kamau 2003). Despite this, De Lange (2011) found that significant monies are wasted each year as a result of poor management of public procurement policies. Therefore, staff in the public sector should be managed to ensure that they comply with the relevant regulations, policies and procedures.

\section{Service delivery}

Public procurement is used as a strategic tool to enhance government performance and the quality of services and is thus central to the delivery of public services (Vellapi 2010). According to the World Bank (2012:10), public procurement programmes have a direct bearing on public service delivery, results, performance, consolidation and completion.

Public services can be defined as services that are funded with public money and are delivered by or on behalf of government. Improving public service delivery is one of the biggest challenges for all countries, as public services are a key determinant of quality of life and poverty reduction. The challenge is particularly apparent in Africa, where historically the quality of service provision has been poor and the needs of the poor continuously increase (Besley \& Ghatak 2007). However, globally, the public sector is facing pressure to deliver more effective and efficient ${ }^{1}$ public services to citizens despite a multitude of socio-economic and global challenges that governments are facing (Price Waterhouse Coopers 2007).

\section{The Zimbabwe public sector}

In Zimbabwe, the public sector is that part of the economy responsible for the provision of various services by public entities (Dube \& Danescu 2011). The composition of the public sector differs from country to country, but generally the public sector is composed of such services as the provision of education, healthcare services, communication and postal services, power generation and distribution, and water and sanitation, amongst others. The public sector provides services that benefit the society at large, from street lighting to public education that promotes equal opportunity (Dube \& Danescu 2011).

\section{Public sector organisation}

A public sector organisation is one that is owned and operated by the government on behalf of the public (Dube \& Danescu 2011). According to Rainey and Bozeman (2000:448), private sector organisations are controlled by private individuals or entities and have to function within the government environments of politics, legislation and public administration. Public sector organisations commonly provide services for the public or citizens of a country regardless of an individual's ability to pay for the service. Effective governments seek to improve the standard of living of citizens through ensuring access to essential services, such as health, education, water and sanitation, electricity, and transport (World Bank 2014).

In the public sector, services are subsidised. For example, public transport organisations, such as the railways, charge a minimal fee to the public, and the majority of the costs for sustaining the entity are funded from the central or local government. The responsibility for protecting the safety of local citizens is undertaken by public sector organisations such as the police and fire departments (Flynn 2007).

However, the public sector also works with private sector organisations when a government contracts private business

1.'Effective' refers to the capability to produce desired results, whilst 'efficient' refers
to the extent to which time or effort is well used for the intended task or purpose to the extent to which time or effort
(Price Waterhouse Coopers 2007). 
to perform work on a specific public project (Hilbert \& Swindell 2013:242). Governments enter into various types of arrangements when building roads and bridges, for example, bringing in new sources of financing for funding public infrastructure and service needs, and the engagement of such contractors is done by the public entities through the public procurement system (Barlow, Roehrich \& Wright 2010).

In Zimbabwe, in terms of the Procurement Act (Chapter 22:14), (Act No. 2 of 1999), Section 2 (b)(c) (Zimbabwe Government 1999), public sector organisations are made up of ministries, departments or other divisions of government or statutory bodies, and local (both urban and rural) authorities.

\section{An overview of the public procurement process in Zimbabwe}

The public procurement process is represented by a set of rules, policies and procedures that specify how government procurement activities are supposed to be carried out (Azeem 2007). In Zimbabwe, the Procurement Act summarises procurement regulations and processes that are detailed in the Procurement Regulations (Zimbabwe Government 2002).
Figure 1 outlines the public procurement process adopted by Zimbabwe (Zimbabwe Government 2008).

The Procurement Act (Chapter 22:14), (Act No. 2 of 1999) (Zimbabwe Government 1999) and the Procurement Regulations, Statutory Instrument 171 of 2002 (Zimbabwe Government 2002) constitute the legal framework for public procurement in Zimbabwe.

The SPB, the regulatory body for public procurement in Zimbabwe, was established in terms of Section 4 of the Procurement Act (Zimbabwe Government 1999) and was gazetted in 2002.

The Procurement Regulations, Statutory Instrument 171 of 2002 (Zimbabwe Government 2002) were passed by Parliament and approved by the President in 2002. They outline the public procurement procedures to be used in government, including the different procurement methods, the procurement cycles and other procedural requirements.

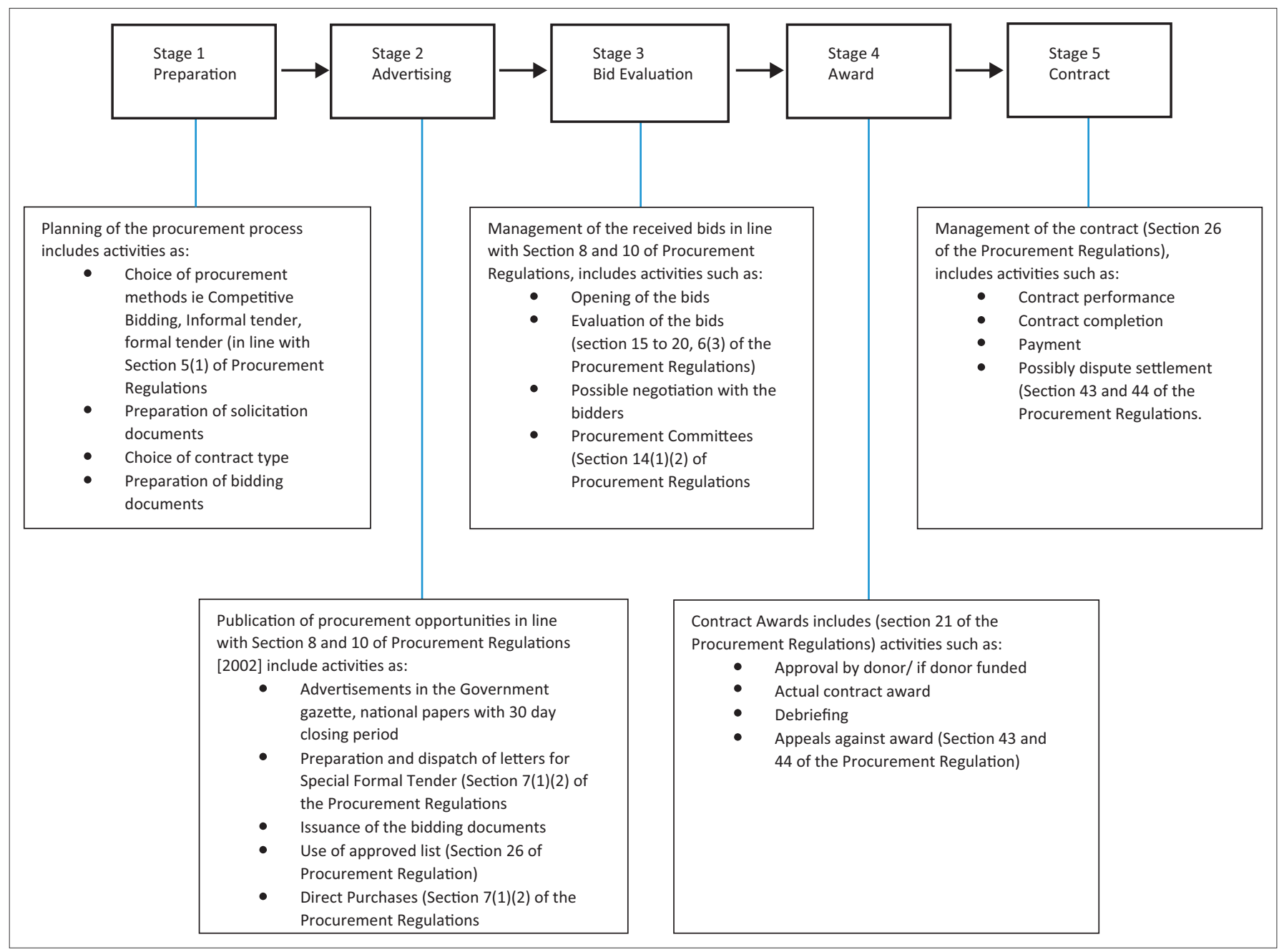

Source: Adapted from the Procurement Act [Chapter 22:14], Act No. 2 of 1999 (Zimbabwe Government 1999) and the Procurement Regulations, Statutory Instrument 171 of 2002 (Zimbabawe Government 2002)

FIGURE 1: Stages in the public procurement process in Zimbabwe. 


\section{Research methodology}

This study is descriptive as it describes the public procurement process in Zimbabwe. It is also exploratory as it aims to identify the challenges in the Zimbabwean public sector that impact on service delivery. The study population consisted of 25 ministries and 52 public entities in Zimbabwe. Semi-structured in-depth interviews were conducted with procurement staff at two ministries and three public entities (Table 1). Two ministries were selected because they provide critical services, namely health and transport. Convenience sampling was used to select the public entities. Three public entities were selected on the basis of the services they provide, namely energy, the distribution of antiretroviral drugs, and fuel.

A semi-structured interview guide, consisting of the following five sections, was used to collect the data:

- general organisational structure

- human resources

- finance and budgeting

- public procurement legal framework

- the public procurement process.

Each section included clearly structured open-ended questions. Interviews were recorded and transcribed verbatim to ensure that the findings were accurate. Qualitative data was analysed using content analysis, which entails identifying themes and key words in the recordings of the interviews (Wood et al. 2005). Data were classified into categories and then unitised.

In order to ensure the validity of the interview guide, it was pilot tested by two qualified academics at a tertiary institution. The participants were requested to make notes regarding areas of the interview guide which were difficult to either understand or respond to. This feedback helped to ensure the face and content validity of the interview guide. In order to ensure reliability of the data, interviews were recorded using a digital voice recorder to ensure that the data collected was accurate.

TABLE 1: List of participants.

\begin{tabular}{ll}
\hline Interviewee & Position \\
\hline Participant 1 & Procurement Officer: Ministry of Health and Child Welfare \\
Participant 2 & $\begin{array}{l}\text { Administrator - Procurement and Contracts. Ministry of } \\
\text { Transport and Infrastructural Development }\end{array}$ \\
Participant 3 & $\begin{array}{l}\text { Procurement Officer: National Aids Council } \\
\text { Participant 4 }\end{array}$ \\
Participant 5 & $\begin{array}{l}\text { Procurement Manager. Zimbabwe Power Company Aids Council Procurement Officer. PetroTrade } \\
\text { Zimbabwe }\end{array}$ \\
\hline
\end{tabular}

\section{Findings}

The findings identified various challenges in the public procurement process that detract from service delivery. These challenges are presented according to the different sections of the interview guide.

\section{Section 1: General organisational structure Organisational structure}

All participants stated that procurement for purchases above \$300 000 are centralised at head office level. Such purchases take a long time to process because of bureaucracy and procedural requirements, which require all purchases above $\$ 300000$ to be approved by the SPB.

\section{Level of operation}

The procurement function at all the participating entities is regarded as an operational function, despite its strategic importance. Because procurement is treated as incidental, service delivery suffers as it results in substandard and late delivery of government projects. The procurement function administrators report to other independent structures such as finance and administration or human resources (Table 2). Procurement decisions are not made by the correct staff in the area of public procurement, and poor procurement decisions are made, resulting in the mediocre and late delivery of public services.

\section{Operational system}

The use of manual procurement systems at all the participating public entities results in a prolonged public procurement process. For example, documents need to move back and forth between the procuring entity, the SPB and sometimes the contractors for approval and counter-approval. Documents include adverts for tenders, requests for proposal documents, evaluation reports and tender response submissions by the contractors. As a result, government projects have been delivered late because of the bureaucracy that results from the manual processes. Therefore, service delivery suffers.

As can be seen from Table 2, the ministries and parastatals face the same challenges resulting from the reporting structure of the procurement function and the decision-making level at which it is placed. Procurement is operated as a subfunction of other departments.

\section{Section 2: Human resources}

Number of employees and their procurement background Table 3 presents the number of staff in the procurement departments at the participating public entities.

\begin{tabular}{|c|c|c|}
\hline Participating entity & Level of autonomy of procurement function & Reporting structure \\
\hline Ministry of Health and Child welfare & Reports to other functions & Director Finance and Administration \\
\hline Ministry of Transport and Infrastructural Development & Reports to other functions & Director Finance and Administration \\
\hline Zimbabwe Power Company & Reports to other functions & Director Finance and Administration \\
\hline PetroTrade Zimbabwe & Reports to other functions & Human Resources and Administration Manager \\
\hline National Aids Council & Reports to other functions & Human Resources and Administration Director \\
\hline
\end{tabular}


TABLE 3: Procurement background of employees.

\begin{tabular}{|c|c|c|c|c|}
\hline Participating entity & Employees in procurement & $\begin{array}{l}\text { Suitably qualified employees } \\
\text { in procurement }\end{array}$ & $\begin{array}{l}\text { State Procurement Board training } \\
\text { provided to employees }\end{array}$ & $\begin{array}{l}\text { Employees with relevant } \\
\text { procurement experience }\end{array}$ \\
\hline $\begin{array}{l}\text { Ministry of Health and Child } \\
\text { welfare }\end{array}$ & 2 & 1 & 0 & 1 \\
\hline $\begin{array}{l}\text { Ministry of Transport and } \\
\text { Infrastructural Development }\end{array}$ & 8 & 2 & 0 & 2 \\
\hline Zimbabwe Power Company & 5 & 2 & $10 \dagger$ & 2 \\
\hline PetroTrade Zimbabwe & 2 & 2 & 0 & 2 \\
\hline National Aids Council & 1 & 1 & 0 & 1 \\
\hline
\end{tabular}

$\uparrow$, There are only five procurement staff but State Procurement Board (SPB) training was also provided to five engineers.

The findings suggest that the lack of relevant qualifications, experience and training of public procurement staff has a negative impact on the public procurement process, particularly at the ministries, where the majority of staff handling the public procurement process hold qualifications in areas such as accounting, finance and human resources. The lack of understanding and incorrect interpretation of procurement principles, procedures and regulations prolongs the public procurement process significantly, resulting in delays in the delivery of critical services, such as in the health and transport sectors. This was confirmed by the participants, who explained that the lack of training in public procurement procedures provided by the SPB results in poor interpretation of the public procurement laws and regulations. Hence the need for procurement staff to continuously engage with the SPB on the interpretation of some of the clauses.

\section{Section 3: Finance and budgeting \\ Budgets}

The findings reveal that four participating entities prepare annual budgets. All participants indicated that a major obstacle to procurement is that budgets exist on paper, but that funds from Treasury are unavailable, a situation that is exacerbated by the liquidity challenges the country is experiencing. Because of these fiscal and cash flow challenges experienced in the country, the participants find it difficult to stick to the budgets where the procurement of goods and services depends on the availability of funds. Such funds are not always available as the government is no longer enjoying the support it used to receive from international organisations. In certain cases, the lack of available funds means that procurement contracts awarded to contractors cannot be sanctioned and may take as long as 6 months to 1 year to expedite, thus depriving citizens of key services. Often by the time the funds are available, prices and the delivery period would have changed. This has a negative cost implication for service delivery.

\section{Section 4: Public procurement legal framework}

In Zimbabwe, the two principal directives in public procurement are the Procurement Act (Zimbabwe Government 1999) and the Procurement Regulations (Zimbabwe Government 2002). The Procurement Regulations detail the public procurement procedure in the country.

\section{Awareness of public procurement regulations}

Three participants were aware and two participants partially aware of the Procurement Act (Zimbabwe Government 1999) and the Procurement Regulations (Zimbabwe Government 2002) (Table 4).

The parastatal employees' awareness of procurement regulations can be attributed to the fact that the parastatals have a higher percentage of employees with relevant procurement qualifications and experience. In the ministries, however, a significant number of employees in the procurement department received training in finance and accounting. This is attributed to the fact that the ministries' recruitment is done through the public service commission, whereas the parastatals have direct control over the recruitment of their procurement staff.

\section{Comprehension of public procurement laws}

Whilst the participants have a degree of knowledge of the Procurement Act (Zimbabwe Government 1999) and the Procurement Regulations (Zimbabwe Government 2002), the interpretation thereof is poor, which results in prolonged procurement processes. For example, the time to complete procurement processes for formal tenders takes on average 3 months, as procurement staff interpret certain clauses differently. This challenge could be attributed to the fact that only eight of the 18 staff employed in the participating entities hold a procurement qualification (Table 3).

However, the findings revealed that the participants attribute the time taken to complete the procurement process to the public procurement legal framework, which states the need to involve the SPB. Therefore, the participants are of the opinion that bureaucratic legal requirements in the public procurement process are a challenge that impedes service delivery and increases cost.

TABLE 4: Awareness of public procurement regulations.

\begin{tabular}{llll}
\hline Procuring entity & Aware & Partially aware & Not aware \\
\hline Ministry of Health and Child welfare & $\times$ & $\mathrm{V}$ & $\times$ \\
$\begin{array}{l}\text { Ministry of Transport and Infrastructural } \\
\text { Development }\end{array}$ & $\times$ & $\mathrm{V}$ & $\times$ \\
Zimbabwe Power Company & $\mathrm{V}$ & $\times$ & $\times$ \\
PetroTrade Zimbabwe & $\mathrm{V}$ & $\times$ & $\times$ \\
National Aids Council & $\mathrm{V}$ & $\mathrm{x}$ & $\times$ \\
\hline
\end{tabular}




\section{Procurement manuals}

The unavailability of up-to-date procurement manuals and a code of conduct and ethics results in inconsistencies in the procurement process. Procurement officers in the same entities and across entities handled similar purchase situations differently, which could be as a result of deficient management practices. This results in a number of errors being made in the process and the need to continuously engage the SPB for guidance and direction. This prolongs the public procurement process and delays the delivery of critical services.

The ministries and parastatals that took part in this study face similar challenges as a result of the requirements of the legal framework, especially the bureaucratic processes that have to be followed in the public procurement process. This bureaucracy is mainly caused by the fact that every stage and activity of the process is regulated and is exacerbated by the requirement that all activities, such as approval of tender documents and adverts, tender closing as well as evaluation, must involve the SPB.

\section{Section 5: The public procurement process}

The public procurement process is detailed in the Procurement Regulations (Zimbabwe Government 2002). The regulations detail all the activities to be followed in the process, the methods available, and the procurement cycles for each method. The procurement cycles consist of the preparation stage, advertising, bid evaluation, tender award and contract management (Zimbabwe Government 2002).

\section{Stage 1: Preparation stage}

All participants acknowledged that procurement planning has become a non-event as a result of inadequate resources and late disbursement of funds from Treasury. As a result procurement is carried out on an ad hoc basis.

The legal requirement to use the SPB in the procurement process results in delays in procurement because the SPB has its own pace and method of operation, which is not in tandem with operational expectations of the entities and service levels required by the public. For example, power generation repairs and spares for the power utility are generally above the informal tender threshold and although the requirements are usually urgent such purchases have to pass through the SPB. Consequent delays in the procurement process exacerbate load shedding and impact on other services and downstream industries.

Procurement thresholds and their effect on the public procurement process: All participating entities carry out high-value purchases annually (Table 5). A significant proportion of purchases are above $\$ 300000$. In terms of Statutory Instrument 161 (Zimbabwe Government 2008), all those transactions have to pass through the SPB. The high rate of tenders that pass through the SPB means that they are exposed to the bureaucracy as a result of the procedural
TABLE 5: Average percentage of purchases.

\begin{tabular}{lll}
\hline Procuring entity & $<\mathbf{3 0 0 k}$ & $>$ 300K \\
\hline Ministry of Health and Child Welfare & 55 & 45 \\
Ministry of Transport and Infrastructural Development & 35 & 65 \\
Zimbabwe Power Company & 20 & 80 \\
PetroTrade Zimbabwe & 55 & 45 \\
National AIDS Council & 55 & 45 \\
\hline
\end{tabular}

TABLE 6: Length of approval process.

\begin{tabular}{lll}
\hline Procuring entity & $\begin{array}{l}\text { Draft RFP and } \\
\text { advert }\end{array}$ & $\begin{array}{l}\text { Approval at } \\
\text { SPB }\end{array}$ \\
\hline Ministry of Health and Child Welfare & 5 & 14 \\
$\begin{array}{l}\text { Ministry of Transport and Infrastructural } \\
\text { Development }\end{array}$ & 14 & 35 \\
Zimbabwe Power Company & 1 & 10 \\
PetroTrade Zimbabwe & 2 & 14 \\
National AIDS Council & 2 & 7 \\
\hline
\end{tabular}

RFP, request for proposal; SPB, State Procurement Board.

requirements. The need for documents to move between the procuring entity and the SPB means that procurement takes time to conclude, whilst citizens await service delivery.

Preparation of request for proposal (RFP) documents: All the participating entities confirmed that RFP documents are prepared by the procurement department and technical experts. The procurement department is responsible for checking mandatory and compliance issues in the RFP (as outlined in Section 8.3 of the Procurement Regulations). The technical experts are responsible for drawing up the specifications.

All the participants remarked that functional standard bidding documents are not available, which results in inconsistencies in the RFP documents. Hence RFPs for the same requirements from various entities differ. The approval process also aggravates the problem as the RFPs are approved by different officers even though they are for the same requirements. As a result of these inconsistencies, it was found that bidders make reference to similar tenders, which often results in litigation. Such litigation causes the tender process to stop until the legal process is completed, whilst citizens await service delivery.

Approval of tender documents: Unarguably, the most critical activity of the preparation stage in the public procurement process is the drafting and approval of tender documents by the SPB (as outlined in Section 8.3 of the Procurement Regulations). The main obstacle at this stage in the process is the approval of the RFP, which takes 16 days on average (Table 6). The participants blame this delay on the lack of technical experts at the SPB who have the technical knowledge and capacity to conclusively analyse and approve technical specifications.

\section{Stage 2: Advertising stage}

Determination of closing and publication dates of tenders: The decision regarding the closing dates for all formal tenders is made by the SPB. The regulations state that all formal tenders shall close in a period of not less 
than 30 days, unless prior approval has been obtained from the SPB (as outlined in Sections 8-10 of the Procurement Regulations). Section 8 of the Procurement Regulations states that all formal tenders are required to be published in the Government Gazette, which is published only on Fridays, before it can be published in other newspapers with national circulation. Payment for adverts in the Government Gazette must be made the previous Monday by 11:00. It was found that public entities that fail to meet the Monday deadline for payment for adverts will have their adverts published a week later, which prolongs the procurement process by 2 weeks.

Time taken between approval of the advert and RFP and closing date: It was found that the period from approval of the advert and RFP to the actual publication is between 7 and 21 days (Table 7). The major challenge is the time taken to approve the RFP and the advert at the SPB, which is significantly long. The time taken from the approval of RFPs to the closing date is 45 days on average (Table 7). These delays significantly slow down the procurement process at the expense of service delivery.

\section{Stage 3: Bid evaluation}

The aim of this section was to provide insight into the activities in the evaluation process as well as identifying the challenges in the bid evaluation that detract from service delivery.

Tender openings: Section 12 of the Procurement Regulations (Zimbabwe Government 2002) requires that all formal tenders close at the SPB. Table 8 documents the time that it takes for the procuring entities to be invited to collect the tender documents after tender closing, as well as the time taken by the procuring entities and the SPB to evaluate the tenders.

It takes between 2 and 7 days from the tender opening to the entities collecting tender documents for evaluation (Table 8). Entities collect the tender documents only after

TABLE 7: Period of approval of advert and request for proposal to closing date.

\begin{tabular}{lll}
\hline Procuring entity & $\begin{array}{l}\text { RFP to publication } \\
\text { (days) }\end{array}$ & $\begin{array}{l}\text { RFP to closing } \\
\text { date (days) }\end{array}$ \\
\hline Ministry of Health and Child Welfare & $7-14$ & 45 \\
$\begin{array}{l}\text { Ministry of Transport and Infrastructural } \\
\text { Development }\end{array}$ & 14 & 44 \\
$\begin{array}{l}\text { Zimbabwe Power Company } \\
\text { PetroTrade Zimbabwe }\end{array}$ & 7 & 45 \\
National AIDS Council & $14-21$ & 45 \\
\hline
\end{tabular}

RFP, request for proposal. invitation by the SPB. The invitation depends on the time the SPB takes to sort and prepare these documents for dispatch.

The complete process of collection of documents from the $\mathrm{SPB}$, tender evaluation at entity level and evaluation at SPB can take as long as 6 weeks (Table 8). This is too long, as bidders usually sell available stock to other customers in the meantime. This means that the whole process has to be repeated, resulting in delays in service delivery.

The evaluation committee: Section 14 of the Procurement Regulations (Zimbabwe Government 2002) states that the accounting officers must appoint members of procurement committees, but it is not explicit regarding the number or composition of procurement committees. It was found that in the entities these committees comprise between 5 and 20 members; however, a significant number lack knowledge of procurement processes, resulting in incomprehensive tender evaluations.

In addition, it was found that the evaluation criteria used for evaluating tenders focus on meeting minimum specifications, which results in tenders being awarded to non-performing tenderpreneurs who have mastered the art of responding to tender documents but have little or no capacity to meet contract requirements. This results in late completion and/ or non-completion of projects and delivery of substandard products and service.

Use of approved lists and tender evaluation: Section 25 of the Procurement Regulations (Zimbabwe Government 2002) states that the SPB has the responsibility of registering suppliers, as well as updating categories and lists when new suppliers are registered.

Potential suppliers are not appraised and rated. All participants mentioned this as a major challenge. The participants in this study indicated that any potential supplier that can provide the required documentation and a $\$ 100$ registration fee can register without proper evaluation of its capacity and ability to carry out government contracts. Hence, tender evaluation bidders may meet the minimum requirements of the tender document but on award of contract may fail to perform.

Based on these findings, it can also be concluded that incompetency of service providers as a result of deficiencies in the bid evaluation process may be a factor in poor service delivery.

TABLE 8: Days taken to collect tender documents and evaluation periods.

\begin{tabular}{|c|c|c|c|}
\hline Procuring entity & Collection by entities & Evaluation by entities & SPB evaluation \\
\hline Ministry of Health and Child Welfare & 7 & 15 & 14 \\
\hline Ministry of Transport and Infrastructural Development & 2 & 15 & 10 \\
\hline Zimbabwe Power Company & 7 & 15 & 10 \\
\hline PetroTrade Zimbabwe & $3-6$ & 15 & 10 \\
\hline National Aids Council & 7 & 15 & 14 \\
\hline
\end{tabular}




\section{Stage 4: Award}

Award communication: All participants speculated that the notification of tender results by the SPB takes between 5 and 14 days, and winning bidders are invited to sign contracts within 4-21 days thereafter. This results in further prolonging the procurement tender process and delivery periods of products and services.

Appeal procedure: In terms of Section 43 of the Procurement Act (Zimbabwe Government 1999), losing bidders have the right to appeal a tender decision within 20 days with the administration court, if they are unsuccessful and are not satisfied with the tender decision. The participants suggested that the legal process takes as long as 3-6 months to conclude. This means that the quoted price of the winning bid is no longer valid, resulting in the procurement process having to start all over again.

\section{Stage 5: Contract management}

Contract performance monitoring and the role of the SPB: It was found that whilst the participating procuring entities have their own initiatives for contract monitoring, the SPB plays no role in contract performance monitoring. It was felt by participants that the SPB should play an active role in contract performance monitoring, as the SPB is the custodian of the supplier lists and supervisor of the implementation of public procurement. It was determined from the interviews that the SPB, on the other hand, is of the opinion that dealing with non-performing or poorly performing contractors is a contractual matter concerning the procuring entity and the contractors. Failure to monitor contract performance results in non-completion and/or late completion of government projects; contractors go unpunished whilst citizens are denied a service.

Procurement audits: It was found that the SPB is not carrying out procurement audits at the procuring entities, which according to Section 6(3) of the Procurement Regulations (Zimbabwe Government 2002) is the SPB's responsibility. The procurement audits are useful in identifying challenges and problems that the procuring entities face in the procurement process, as well as in implementing measures to improve the procurement process. The absence of these audits has resulted in entities repeating the same errors and the procurement process being subject to the same challenges and litigation by aggrieved bidders, resulting in the stalling of service delivery.

\section{Conclusion}

Public procurement is a process by which government agencies and other public entities choose and contract commercial companies to provide goods and services. In Zimbabwe, public procurement is centralised at the SPB. The mandate of the SPB is to regulate and manage the procurement processes for all public entities in Zimbabwe, in line with public procurement legislation. The need to comply with SPB processes is the reason why so many projects are behind schedule. It has been reported that it is government's intention to streamline the operations of the SPB, which would improve efficiency in the public sector (The Herald 20 January 2013).

Against this background, the primary aim of this article was to identify the challenges faced in the procurement process that detract from service delivery in Zimbabwe. Numerous challenges were identified, mainly:

- the lack of strategic recognition of the procurement function

- the lack of professional, managerial and leadership skills

- the lack of funds from Treasury

- the lack of understanding of procurement policy and regulations

- the lack of accountability in the procurement process.

It is recommended that the public procurement legal framework be reformed. The Procurement Act and Regulations should allow for the decentralisation of public procurement and eliminate the current procurement threshold of $\$ 300000$. These changes could result in a quicker turnaround time of the procurement process and thus improve service delivery.

In addition, the powers of the SPB could be streamlined so that they could monitor procuring entities and diligently carry out procurement audits to ensure compliance and prevent abuse of the authority granted the procuring entities.

It is also recommended that public procurement staff be provided with training in order to improve their understanding and interpretation of the Procurement Act and Regulations.

The main limitation of this study is that challenges were identified based on interviews with participants at only five public entities. Consequently, it is possible that not all challenges in public procurement in Zimbabwe have been identified. However, the identified procurement challenges form the basis of a questionnaire which will be sent to the remaining ministries and parastatals to determine the extent of these challenges and whether there are any other challenges. Therefore, a complete census rather than a sample will be used in order to draw conclusive findings.

In conclusion, it can be deduced that the lengthy period of time required to conclude the public procurement process detracts from service delivery. The time delays are a result of procedural requirements demanded by the public procurement legal framework.

\section{Acknowledgements Competing interests}

The authors declare that they have no financial or personal relationships which may have inappropriately influenced them in writing this article. 


\section{Authors' contributions}

A.D. (University of KwaZulu-Natal) collected and analysed the data and M.J.A.N. (University of KwaZulu-Natal) wrote the manuscript.

\section{References}

Azeem, V., 2007, Impact of the Public Procurement Act, 2003 (Act 663), Integrity Initiative, Accra.

Barlow, J., Roehrich, J.K. \& Wright, S., 2010, 'De facto privatization or a renewed role for the EU? Paying for Europe's healthcare infrastructure in a recession' Journal of the Royal Society of Medicine 103, 51-55. http://dx.doi.org/10.1258/ journal of the Roy 2009.090296

Besley, T. \& Ghatak, M., 2007, 'Reforming public service delivery', Journal of African Economies AERC suppl. 1(16), 127-156. http://dx.doi.org/10.1093/jae/ejm026

De Lange, S., 2011, 'Irregular state expenditure jumps 62\%', Business Day, viewed 20 March 2014, from http://www.businessday.co.za

Dobler, D.W., Burt, D.N. \& Starling, S.L., 2003, World class supply management: The key to supply chain management, McGraw-Hill, Boston.

Dube, S. \& Danescu, D., 2011, Supplemental guidance: Public sector definition Institute of Internal Auditors, viewed 08 September 2014, from http://www. global.theiia.org/standards-guidance

Flynn, N., 2007, Public sector management, 5th edn., Sage, London.

Hilbert, C. \& Swindell, D., 2013, 'Collaborative service delivery: What every local government manager should know', State and Local Government Review 45(4), 240-254. http://dx.doi.org/10.1177/0160323X13513908

Hui, W.S., Othman, R.O., Normah, O., Rahman, R.A. \& Haron, N.H., 2011, 'Procurement issues in Malaysia', International Journal of Public Sector Management 24(6), 567593. http://dx.doi.org/10.1108/09513551111163666

Lisa, I., 2010, 'Compliance culture - A conceptual framework', Journal of Management and Organisation 19(7), 702-714.

Mahmood, S.A., 2010, 'Public procurement and corruption in Bangladesh: Confronting the challenges and opportunities', Journal of Public Administration and Policy Research 2(6), 103-111.

Musanzikwa, M., 2013, 'Public procurement system challenges in developing countries: The case of Zimbabwe', International Journal of Economics, Finance and Management Sciences 1(2), 119-127. http://dx.doi.org/10.11648/j.ijefm. 20130102.18
Monczka, R., Handfield, R., Giunipero, L. \& Patterson, J.L., 2008, Purchasing and supply chain management, Cengage Learning, Melbourne.

Odhiambo, W. \& Kamau, P.N., 2003, 'Public procurement reforms: Lessons from Kenya, Tanzania and Uganda', OECD Technical Paper No 208, March 2003, Heinrich Boll Foundation, Berlin

Price Waterhouse Coopers, 2007, The road ahead for public service delivery: Delivering on the customer promise, Public Service Research Centre, Price Waterhouse Coopers, viewed 08 September 2014, from http://www.pwc.com/gx/en/psrc/ global/the-road-ahead-for-public-service-delivery.html

Rainey, G.H. \& Bozeman, B., 2000, 'Comparing public and private organisations: Empirical research and the power of a priori', Journal of Public Administration Research and Theory 10(2), 447-470. http://dx.doi.org/10.1093/oxfordjournals. jpart.a024276

Roodhooft, F. \& Abbeele, A.V.D., 2006, 'Public procurement: Consulting services evidence and comparison with private companies', International Journal of Public Sector Management 19(5), 490-512. http://dx.doi.org/10.1108/09513 550610677799

United Nations Development Programme (UNDP)/IAPSO, 2006, Sustainable procurement guidelines: Economic, social and environmental considerations in public procurement, viewed 30 October 2014, from http://www.iapso.org/pdf/ gbg_master.pdf

Uyarra, E. \& Flanagan, K., 2009, 'Understanding the innovation impacts of public procurement', Manchester Business School Working Paper No 574, viewed 14 May 2013, from http://www.mbs.ac.uk/research/workingpapers

Vellapi, M., 2010, 'Public procurement for sustainable development', Research paper on Sustainable Public Procurement, Ministry of Highways, Sri Lanka.

Wood, M.R.R, Clark, M.A., Wilkie, E. \& Szivas, E., 2005, Researching and writing dissertations in business management, Thomson, Melbourne.

World Bank, 2012, Why reform public procurement: Towards better governance and public sector performance in the Middle East and North Africa, viewed 17 July 2014 from http://www.worldbank.org/content/dam/Worldbank/document/MNA/Why ReformPublic_Procurement

World Bank, 2014, The public sector, viewed 13 November 2014, from http://data worldbank.org/topic/public-sector

'Zimbabwe: End of an era for the state procurement board', The Herald, 20 January 2013, p. 3.

Zimbabwe Government, 2008, Statutory Instrument 161 of 2002, Harare.

Zimbabwe Government, 2002, Procurement Regulations, Statutory Instrument 171 of 2002, Harare.

Zimbabwe Government, 1999, Procurement Act [Chapter 22:14], Act No. 2 of 1999, Harare. 